\title{
Variations stylistiques
}


This page intentionally left blank 


\section{Variations stylistiques}

Cours de grammaire avancée

Diane M. Dansereau

University of Colorado Denver

Yale UNIVERSITY PRESS

New Haven \& London 
Published with assistance from the Louis Stern Memorial Fund.

Copyright (C) 2016 by Yale University.

All rights reserved.

This book may not be reproduced, in whole or

in part, including illustrations, in any form (beyond that copying permitted by Sections 107 and 108 of the U.S. Copyright Law and except by reviewers for the public press), without written permission from the publishers.

Yale University Press books may be purchased

in quantity for educational, business, or promotional use. For information, please e-mail sales.press@yale.edu (U.S. office) or sales@yaleup.co.uk (U.K. office).

Editors: Tim Shea and Sarah Miller

Publishing Assistant: Ashley E. Lago Manuscript Editor: Rose Vekony

Production Editor: Ann-Marie Imbornoni Production Controller: Katie Golden Set in Joanna, Nobel, and Avenir type by Newgen North America.

Printed in the United States of America.

Library of Congress Control Number: 2015952712 ISBN 978-0-300-19846-I (cloth : alk. paper)

A catalogue record for this book is available from the British Library.

This paper meets the requirements of ANSI/NISO Z39.48-1992 (Permanence of Paper).

$\begin{array}{llllllllll}\text { IO } & 9 & 8 & 7 & 6 & 5 & 4 & 3 & 2 & \text { I }\end{array}$ 
À Francine et Michel 
Pour le site web de Variations stylistiques, voir yalebooks.com/dansereau. 